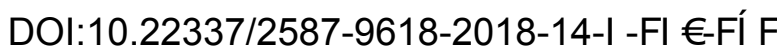

\title{
FUNDAMENTAL ERROR OF THE THEORY OF DURABLE RESISTENCE AND STANDARDS FOR REINFORCED CONCRETE
}

\author{
Rudolf S. Sanzharovsky ${ }^{1}$, Tatyana N. Ter-Emmanuilyan ${ }^{2}$, \\ Maxim M. Manchenko ${ }^{3}$ \\ ${ }^{1}$ L.N. Gumilyov Eurasian National University, Astana, KAZAKHSTAN \\ ${ }^{2}$ Russian University of Transport (RUT - MIIT), Moscow, RUSSIA \\ ${ }^{3}$ Krylov State Research Centre, Saint-Petersburg, RUSSIA
}

\begin{abstract}
This article identifies and investigates the errors in the foundations of the modern theory of creep of reinforced concrete caused by the use of the principle of superposition, which is an extensive interpretation of the principle (scheme) of the linear superposition of Boltzmann. The results of the analysis published by the authors in the journal of Structural Mechanics of Engineering Constructions and Buildings No. 6 of 2017 and No. 3 of 2016 are supplemented. The article was written in accordance with the recommendations of the round table held in the RUDN University on June 9, 2016, under the guidance of D.Sc., Prof. S.N. Krivoshapko.
\end{abstract}

Keywords: elastoplastic deformations of concrete, creep theory of concrete,

long-term resistance of reinforced concrete, modern building codes

\section{ОШИБКИ В ТЕОРИИ ПОЗЛУЧЕСТИ ЖЕЛЕЗОБЕТОНА И СОВРЕМЕННЫЕ НОРМЫ}

\author{
Р.С. Санжсаровский ${ }^{1}$, Т.Н. Тер-Эммануильян ${ }^{2}$, М.М. Манченко $^{3}$ \\ ${ }^{1}$ Евразийский национальный университет им. Л.Н. Гумилева, г. Астана, КАЗАХСТАН \\ ${ }^{2}$ Российский университет дружбы народов, г. Москва, РОССИЯ \\ Крыловский государственный научный центр, г. Санкт-Петербург, РОССИЯ
}

\begin{abstract}
Аннотация: В данной статье отмечаются и исследуются ошибки, имеющиеся в основах современной теории ползучести железобетона, вызванные использованием принципа суперпозиции, который представляет собой обширную интерпретацию принципа (схемы) линейной суперпозиции Больцмана. Результаты анализа, опубликованные авторами ранее в журнале «Строительная механика инженерных сооружений и зданий» (№6 за 2017 год и №3 за 2016 год), здесь существенно дополнены. Настоящая статья написана в соответствии с рекомендациями круглого стола, проведенного в Российском университете дружбы народов (РУДН) 9 июня 2016 года под руководством д.т.н., проф. С.Н. Кривошапко.
\end{abstract}

Ключевые слова: упругопластические деформации бетона, теория ползучести бетона, долговременное сопротивление железобетона, современные строительные нормы

The principle of superposition is the basis of both the modern scientific creep theory of concrete, which is called the "world harmonized format" by foreign scientists, and the developments "in recent decades of international standardization institutions ... for recommendations, norms and technical guidance documents" [1, 2, 3]. These works also indicate that McHenry in USA (1943) "substantiated this trend by experimental studies of the creep of hermetic specimens using the principle of superposition which is characteristic for the theory of Volterra". 
We give the basic law of creep of concrete in the original notation [1]:

$$
\begin{aligned}
\varepsilon_{\sigma}(t)= & \sigma\left(t_{0}\right) J\left(t, t_{0}\right)+ \\
& +\int_{t_{0}}^{t} J\left(t, t^{\prime}\right) d \sigma\left(t^{\prime}\right)
\end{aligned}
$$

where $\varepsilon_{\sigma}(t)$ is the complete strain from stress $\sigma(t)$;

$$
J\left(t, t^{\prime}\right)=\frac{1}{E_{c}\left(t^{\prime}\right)}+\frac{\varphi\left(t, t^{\prime}\right)}{E_{c}\left(t^{\prime}\right)}
$$

- compliance function; $E_{c}\left(t^{\prime}\right)$ is nonstationary modulus of elasticity; $\varphi\left(t, t^{\prime}\right)$ is nonstationary creep characteristic considering ageing.

In scientific publications (1) is usually integrated by parts, thus obtaining

$$
\begin{aligned}
& \varepsilon_{\sigma}(t)=\frac{\sigma(t)}{E_{c}(t)}- \\
& -\int_{t_{0}}^{t} \sigma\left(t^{\prime}\right) \frac{\partial}{\partial t^{\prime}}\left[\frac{1}{E_{c}\left(t^{\prime}\right)}+\frac{\varphi\left(t, t^{\prime}\right)}{E_{c}\left(t^{\prime}\right)}\right] d t^{\prime} .
\end{aligned}
$$

The term

$$
\frac{\varphi\left(t, t^{\prime}\right)}{E_{c}\left(t^{\prime}\right)}
$$

is a measure of the creep of concrete $C\left(t, t^{\prime}\right)$ used in publications in our country, which is preferable to application of the creep characteristics in the processing of experiments. We emphasize that ageing of concrete is taken into account in $\varphi\left(t, t^{\prime}\right)$ and $C\left(t, t^{\prime}\right)$, and the modulus of elastic-instantaneous deformation Ec ( $t$ ') essentially depends on the age of the concrete.

Equations (1), (1') are substantiated by two fundamental assumptions: the principle of linear connection between stresses and strains

$$
\varepsilon_{\sigma}\left(t, t^{\prime}\right)=\sigma\left(t^{\prime}\right) J\left(t, t^{\prime}\right)
$$

the principle of superposition, verbally formulated in various versions in numerous well-known publications on the theory of creep of concrete, reference books, for example in [9]. Serious mistakes in (1) make the normative theory inconsistent with Eurocode, unreliable and uneconomical. Losses from such norms and calculations are significant as annual global volume of usage of concrete and reinforced concrete is 4 billion $\mathrm{m}^{3}$. Let us also recall the tragedy of the collapse of the Transvaal Park (Moscow, 2004), caused by creep problems in concrete.

We note that the article has no relation to the "ongoing disputes, ... discrepancies and uncertainties" existing in this section of creep of reinforced concrete. Also, in this paper we do not discuss a different point of view. We, using the Eurocode system, identify and analyze the errors in that area of creep, where, as the leaders and developers of norms indicate, there is a "steady consensus" $[1,2,3]$.

The main mathematical error in (1) lies in its basis - the principle of superposition, which appeared in the theory of reinforced concrete after the work of McHenry. This principle incorrectly builds the core of creep, incorrectly describes the processes of changing instantaneous deformations and creep strains. The errors in the principle of superposition can be determined in various ways: for example, by constructing and solving a differential equation corresponding to a linear connection ( $\left(1^{\prime \prime}\right)$; sololving the inverse problem of classical mechanics; analysing the value of the total strain rate corresponding to $\left(1^{\prime \prime}\right)$.

Applying the last method the following is obtained:

$$
\begin{aligned}
& \mathrm{v}_{\sigma}\left(t, t^{\prime}\right)=\dot{\sigma}\left(t^{\prime}\right) \cdot J\left(t, t^{\prime}\right)+ \\
& +\sigma\left(t^{\prime}\right) \frac{\partial J\left(t, t^{\prime}\right)}{\partial t}+\sigma\left(t^{\prime}\right) \frac{\partial J\left(t, t^{\prime}\right)}{\partial t^{\prime}}
\end{aligned}
$$

From this formula it is clearly seen that four terms, caused by the rate of change in the compliance factor are lost in the main law (1): 


$$
\begin{aligned}
& -\sigma\left(t^{\prime}\right) \frac{\dot{E}_{c}\left(t^{\prime}\right)}{E_{c}^{2}\left(t^{\prime}\right)}+\sigma\left(t^{\prime}\right) \frac{1}{E_{c}\left(t^{\prime}\right)} \frac{\partial \varphi\left(t, t^{\prime}\right)}{\partial t}+ \\
& +\sigma\left(t^{\prime}\right) \frac{1}{E_{c}\left(t^{\prime}\right)} \frac{\partial \varphi\left(t, t^{\prime}\right)}{\partial t^{\prime}}- \\
& -\sigma\left(t^{\prime}\right) \varphi\left(t, t^{\prime}\right) \frac{\dot{E}_{c}\left(t^{\prime}\right)}{E_{c}^{2}\left(t^{\prime}\right)}
\end{aligned}
$$

and the value of these terms is comparable with that of the remaining term. These losses cause considerable discrepancies between the theory and the experiments described in the scientific literature, e.g. [7].

Opposite mathematical actions, first differintiation and then integration, are performed (and without any need) over the known result $\left(1^{\prime \prime}\right)$ of the classical theory in the priciple of superposition.

One term for instantaneous deformations and several terms for creep deformations are lost in the process of differentiation. After integration, the losses are included into the values of deformations, and then into the theory of design calculations.

The principle of superposition distorts the classical linear connection (1"), causing three types of errors $[4,5,8]$, distorting the theory of creep of concrete:

1. incorrectly determines the values of shortterm linear strains;

2. incorrectly finds the expression of a nucleus describing the process of changing linear creep strains;

3. erroneously classifies as instantaneous elastic deformations to creep strains.

Let us consider them in more detail.

1. The rate of elastic deformation equals

$$
\dot{\varepsilon}_{\mathrm{y}}\left(t^{\prime}\right)=\dot{\sigma}\left(t^{\prime}\right) \frac{1}{E_{c}\left(t^{\prime}\right)}+\sigma\left(t^{\prime}\right) \frac{\partial}{\partial t^{\prime}} \frac{1}{E_{c}\left(t^{\prime}\right)}
$$

Integrating, we obtain

$$
\begin{aligned}
& \varepsilon_{\mathrm{y}}(t)-\varepsilon_{\mathrm{y}}\left(t_{0}\right)=\int_{t_{0}}^{t} \frac{1}{E_{c}\left(t^{\prime}\right)} d \sigma\left(t^{\prime}\right)+ \\
& +\int_{t_{0}}^{t} \sigma\left(t^{\prime}\right) \frac{\partial}{\partial t^{\prime}} \frac{1}{E_{c}\left(t^{\prime}\right)} d t^{\prime}
\end{aligned}
$$

Integrating the first term by parts, we find

$$
\begin{aligned}
& \varepsilon_{\mathrm{y}}(t)-\varepsilon_{\mathrm{y}}\left(t_{0}\right)=\frac{\sigma(t)}{E_{c}(t)}-\frac{\sigma\left(t_{0}\right)}{E_{c}\left(t_{0}\right)}- \\
& -\int_{t_{0}}^{t} \sigma\left(t^{\prime}\right) \frac{\partial}{\partial t^{\prime}} \frac{1}{E_{c}\left(t^{\prime}\right)} d t^{\prime}+ \\
& +\int_{t_{0}}^{t} \sigma\left(t^{\prime}\right) \frac{\partial}{\partial t^{\prime}} \frac{1}{E_{c}\left(t^{\prime}\right)} d t^{\prime}
\end{aligned}
$$

Hence the short-term deformation equals

$$
\varepsilon_{\mathrm{y}}(t)=\frac{\sigma(t)}{E_{c}(t)}
$$

It is also clear that the first term under the integral sign ( $\left(1^{\prime}\right)$ is superfluous, and the use of the overlapping principle in (1) and $\left(1^{\prime}\right)$

$$
\begin{aligned}
& \varepsilon_{\mathrm{y}}(t)=\frac{\sigma\left(t_{0}\right)}{E_{c}\left(t_{0}\right)}-\int_{t_{0}}^{t} \frac{1}{E_{c}\left(t^{\prime}\right)} d \sigma\left(t^{\prime}\right)= \\
& =\frac{\sigma(t)}{E_{c}(t)}-\int_{t_{0}}^{t} \sigma\left(t^{\prime}\right) \frac{\partial}{\partial t^{\prime}} \frac{1}{E_{c}\left(t^{\prime}\right)} d t^{\prime}
\end{aligned}
$$

is strongly erroneous.

The principle of overlapping erroneously reconstructs the actual, real elastic linear model of concrete with the $E_{\mathrm{c}}(t)$ module; the prinicple attaches to it a non-existent and unreal model of a linear viscous fluid with a viscosity coefficient

$$
K_{1}\left(t^{\prime}\right)=\frac{E_{\mathrm{c}}^{2}\left(t^{\prime}\right)}{\dot{E}_{c}\left(t^{\prime}\right)},
$$

thus forming Maxwell's scheme.

Let us consider an example, putting $\sigma(t)=\sigma_{0}=$ const in (3), (4), we will receive 


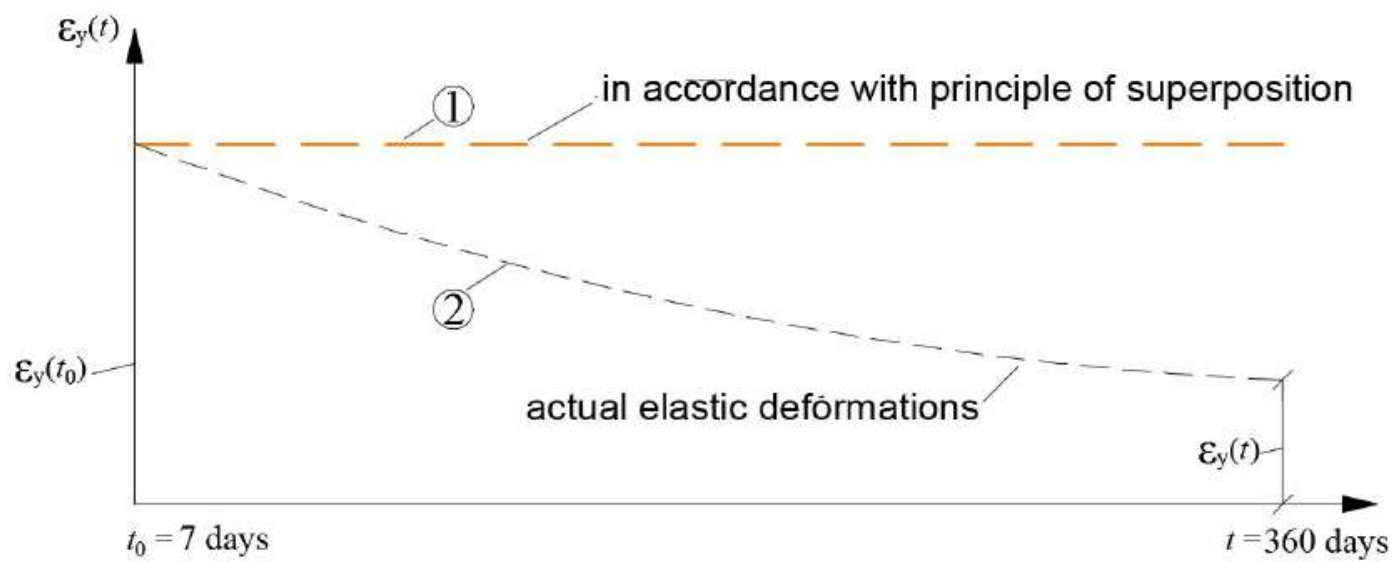

Figure 1. Comparison of $\varepsilon_{\mathrm{y}}\left(t_{0}\right)$ and $\varepsilon_{\mathrm{y}}(t)$.

$$
\varepsilon_{\mathrm{y}}(t)=\frac{\sigma_{0}}{E_{c}(t)}
$$

and

$$
\varepsilon_{\mathrm{y}}\left(t_{0}\right)=\frac{\sigma_{0}}{E_{c}\left(t_{0}\right)}=\text { const }
$$

Comparison of these deformations is shown in Fig. 1.

Curve 2 in Fig. 1 corresponds to the VNIIG data on the changing of modulus of elasticity with time. Errors in the value of elastic deformation are about $\approx 300 \%$ at $\mathrm{t}=360$ days.

2 . In the region of creep deformations, the number of additional (fictitious) bodies arising due to an incorrect scheme for constructing the creep kernel (hereditary function of type I) increases substantially. It depends on the form of the function $\varphi\left(t, t^{\prime}\right)$ describing the nonstationary creep characteristic in the main law (1). We write this function in a well-known, widely used in the scientific literature form

$$
\frac{\varphi\left(t, t^{\prime}\right)}{E_{\mathrm{c}}\left(t^{\prime}\right)}=\frac{\varphi_{\infty}\left(t^{\prime}\right)\left[1-e^{-\gamma\left(t-t^{\prime}\right)}\right]}{E_{c}\left(t^{\prime}\right)},
$$

where $\varphi_{\infty}\left(t^{\prime}\right)$ is a function considering the ageing of concrete.

In the famous monograph of Prokopovich I.E. the creep behavior $\varphi\left(t, t^{\prime}\right)$ used by foreign scientists has the designation $\bar{C}(t, \tau)$, these are identical quantities.
In case (5), the fundamental law (1) forms four extra (fictitious) bodies: two Foigt type bodies and two viscous elements connected in series with each other. Deformations of these bodies are equal

$$
\begin{aligned}
& \varepsilon_{1 \phi}(t)=\int_{t_{0}}^{t} \sigma\left(t^{\prime}\right) \frac{1}{\eta_{1 \phi}\left(t^{\prime}\right)} e^{-\gamma\left(t-t^{\prime}\right)} d t^{\prime}, \\
& \eta_{1 \phi}\left(t^{\prime}\right)=\frac{E_{\mathrm{c}}\left(t^{\prime}\right)}{\dot{\varphi}_{\infty}\left(t^{\prime}\right)} ; \\
& \varepsilon_{2 \phi}(t)=\int_{t_{0}}^{t} \sigma\left(t^{\prime}\right) \frac{1}{\eta_{2 \Phi}\left(t^{\prime}\right)} d t^{\prime}, \\
& \eta_{2 \phi}\left(t^{\prime}\right)=\frac{E_{\mathrm{c}}^{2}\left(t^{\prime}\right)}{\dot{E}_{c}\left(t^{\prime}\right)} \frac{1}{\varphi_{\infty}\left(t^{\prime}\right)} ; \\
& \varepsilon_{3 \phi}(t)=\int_{t_{0}}^{t} \sigma\left(t^{\prime}\right) \frac{1}{\eta_{3 \phi}\left(t^{\prime}\right)} e^{-\gamma\left(t-t^{\prime}\right)} d t^{\prime}, \\
& \eta_{3 \phi}\left(t^{\prime}\right)=-\frac{E_{\mathrm{c}}^{2}\left(t^{\prime}\right)}{\dot{E}_{c}\left(t^{\prime}\right)} \frac{1}{\varphi_{\infty}\left(t^{\prime}\right)} ; \\
& \varepsilon_{4 \phi}(t)=\int_{t_{0}}^{t} \sigma\left(t^{\prime}\right) \frac{1}{\eta_{4 \phi}\left(t^{\prime}\right)} d t^{\prime}, \\
& \eta_{4 \phi}\left(t^{\prime}\right)=-\frac{E_{\mathrm{c}}\left(t^{\prime}\right)}{\dot{\varphi}_{\infty}\left(t^{\prime}\right)},
\end{aligned}
$$

where $\eta_{1 \phi}, \ldots, \eta_{4 \phi}$ are the viscosity coefficients or the coefficients of internal resistance of the fictitious bodies; moreover, the bodies (8) of Voigt and (9) of the viscous element expand under compression. 
The creep deformations (6) - (9), caused by the effect of the superposition principle on the classical bond $\left(1^{\prime \prime}\right)$, are a fiction; they are also summed up with a short-term fictitious deformation

$$
\begin{gathered}
\varepsilon_{5 \phi}(t)=-\int_{t_{0}}^{t} \sigma\left(t^{\prime}\right) \frac{\partial}{\partial t^{\prime}} \frac{1}{E_{\mathrm{c}}\left(t^{\prime}\right)} d t^{\prime}: \\
\varepsilon_{\sigma \phi}(t)=\sum_{i=1}^{5} \varepsilon_{i \phi}(t),
\end{gathered}
$$

and introduce large errors in the value of the total deformation $\varepsilon_{\sigma}(t)$ determined by the creep law $\left(1^{\prime}\right)$. For example (Recommendations, 1988), at constant stresses, the error from applying the superposition principle for creep strains reaches $100 \%$ :

$$
\frac{\varepsilon_{\mathrm{c \sigma}}(t)_{\text {ошибки }}}{\varepsilon_{\mathrm{c \sigma}}(t)_{\text {принцип }}}=1-\frac{\int_{t_{0}}^{t} \Omega(\tau) f(t-\tau) d \tau}{\Omega\left(t_{0}\right) f\left(t-t_{0}\right) d \tau},
$$

where $\Omega(\tau)$ is "the function of the effect of ageing on the measure of creep";

$f(t-\tau)$ is - "a function that takes into account the increase in time creep measure".

3 . The fact of appearance of a single short-term strain

$$
\frac{1}{E_{\mathrm{c}}\left(t^{\prime}\right)}
$$

in the nucleus of creep of the integral equation $\left(1^{\prime}\right)$ :

$$
\begin{aligned}
& \frac{\partial}{\partial t^{\prime}}\left[\varepsilon_{\mathrm{y}, 1}\left(t^{\prime}\right)+C\left(t, t^{\prime}\right)\right]= \\
& =\frac{\partial}{\partial t^{\prime}}\left[\frac{\varepsilon_{\mathrm{y}}\left(t^{\prime}\right)}{\sigma\left(t^{\prime}\right)}+C\left(t, t^{\prime}\right)\right]
\end{aligned}
$$

led to the temptation of erroneous substitution of the properties of short-term deformation $\varepsilon_{\mathrm{y}, 1}\left(t^{\prime}\right)$ by the properties of deformations of the hereditary type $\varepsilon_{\mathrm{y}, 1}\left(t, t^{\prime}\right)$.

The error is corrected by making new mistakes. Concrete has essentially non-linear properties at short-term and long-term loading. The shortterm load diagram has a falling section and a limited extent, see figure 2 . In the main law (1), (1') only linear deformation

$$
\varepsilon_{\text {л }}(t)=\varepsilon_{\mathrm{y}}(t)
$$

is taken into account, and the nonlinear deformation $\varepsilon_{\mathrm{H}}(t)$ is ignore, see figure 2 . Aleksandrovsky S.V. indicates the reason for this circumstance: "It is very difficult to take into account the dependence of the modulus of elasticity on stresses and age of concrete simultaneously. Therefore, the modern theory of creep of concrete takes into account only a change in the modulus in time ... ".

Let us consider two types of such substitution. The first substitution. A representative forum poses the erroneous task of "taking into account the influence of the pre-history of deformation on the modulus of elastic-instantaneous deformations". The basic equation of the creep theory takes the form (in the original notation):

$$
\begin{aligned}
& \varepsilon(t)=\frac{\sigma(t)}{E_{c}\left(t, t^{\prime}\right)}- \\
& -\int_{t_{0}}^{t} \sigma(\tau) \frac{\partial}{\partial \tau}\left[\frac{1}{E_{c}(t, \tau)}+C(t, \tau)\right] d \tau
\end{aligned}
$$

An "experimentally valid" expression appears for the modulus of elastic deformation of concrete

An "experimentally valid" expression appears for the modulus of elastic deformation of concrete

$$
E_{t, \tau}=E_{t}+a_{n, \tau} \varphi_{t} E_{\tau}
$$

where $\varphi_{t}$ is characteristic of creep of concrete. And other erroneous forms of the main creep law appear 


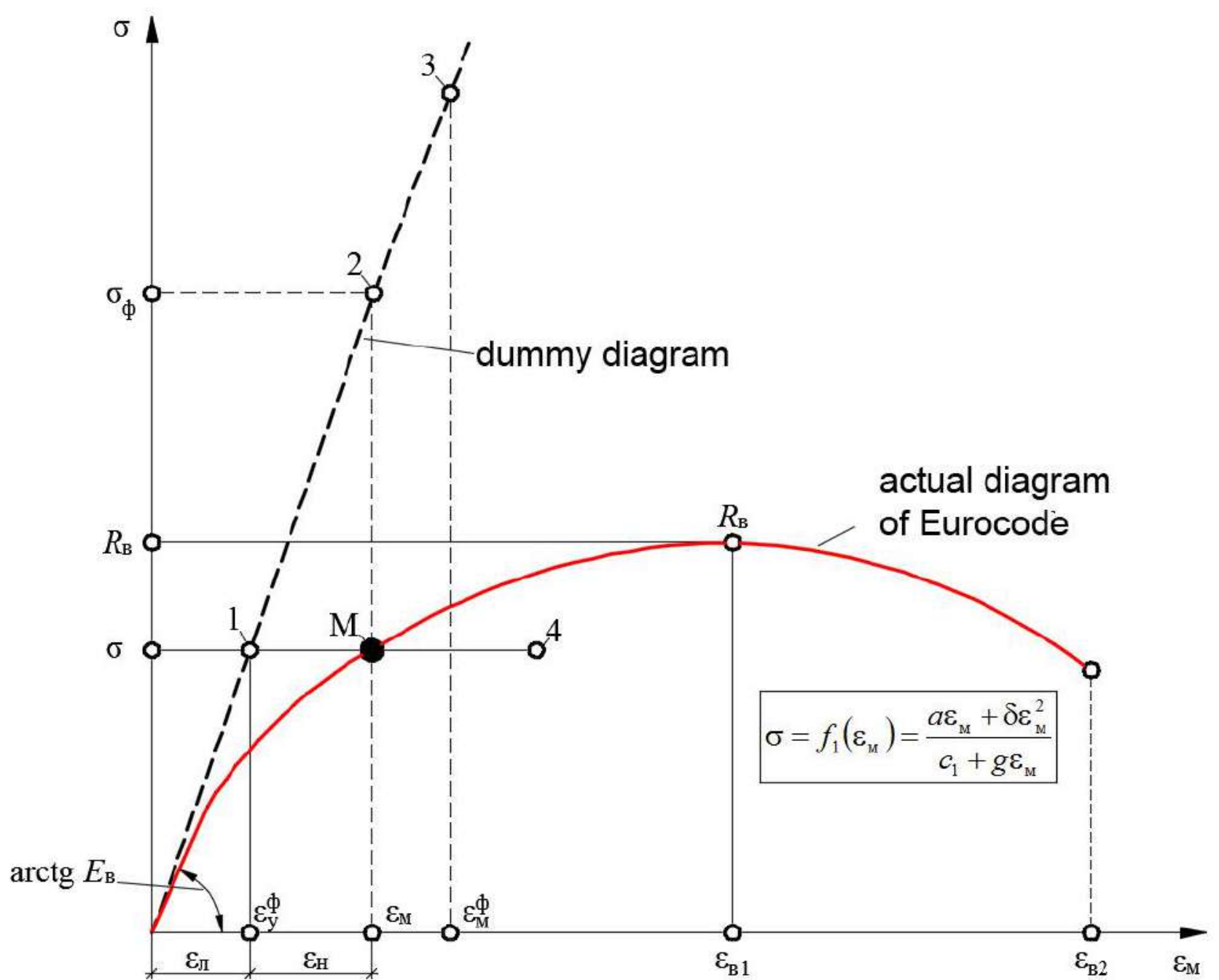

Figure 2. Distortion of the $\sigma$-E diagram of concrete.

$$
\begin{aligned}
& \left.\varepsilon(t)=\frac{\sigma(t)}{E(t)}+\int_{\tau \varepsilon(t)=}^{t} \sigma(\tau) \frac{\partial}{\partial \tau} \chi_{t}(t)+\tau_{t}\right) d \tau-d \tau(\tau)+\int_{\tau_{1}}^{\partial} \sigma(\tau) \frac{\partial \tau}{\partial \tau} \chi(t, \tau) d \tau-
\end{aligned}
$$

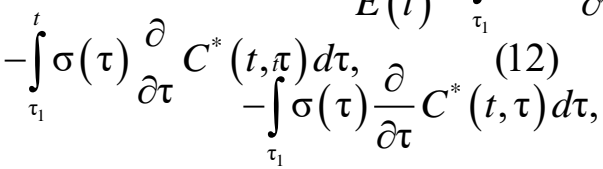

where

$$
\frac{\partial}{\partial \tau} C^{*}(t, \tau)=\frac{\partial}{\partial \tau}\left|\frac{1}{E(\tau)}+C(t, \tau)\right|
$$

$\chi(t, \tau)$ has the name "reducing correction ... to the current specific elastic-instantaneous deformations".

The second substitution. The nonlinear shortterm strain $\varepsilon_{\mathrm{H}}(t)$ is erroneously attributed to the deformation properties of the hereditary type $\varepsilon_{\mathrm{H}}\left(t, t^{\prime}\right)$, the erroneous overlapping principle is used, and, instead of the simple algebraic formula

$$
\varepsilon_{\mathrm{H}}(t)=B_{2}(t) \sigma^{2}(t)
$$

( $B_{2}$ is a known coefficient), the integral following is contrived: 


$$
\begin{aligned}
& \varepsilon_{\text {н }}(t)=\int_{t_{0}}^{t} \sigma\left(t^{\prime}\right) \frac{\partial}{\partial t^{\prime}} \frac{\varepsilon_{\text {н }}\left(t, t^{\prime}\right)}{\sigma\left(t^{\prime}\right)} d t^{\prime} \\
& =\int_{t_{0}}^{t} \sigma\left(t^{\prime}\right) \frac{\partial}{\partial t^{\prime}} C_{\text {н }}\left(t, t^{\prime}\right) d t^{\prime}
\end{aligned}
$$

where $C_{\mathrm{H}}\left(t, t^{\prime}\right)$ is called the measrue of fastflowing creep.

$$
\begin{aligned}
& C\left(t, t^{\prime}\right)+C_{\text {н }}\left(t, t^{\prime}\right)= \\
& =\frac{1}{E_{\mathrm{c}}\left(t^{\prime}\right)}\left[\varphi\left(t, t^{\prime}\right)+\varphi_{\mathrm{H}}\left(t, t^{\prime}\right)\right],
\end{aligned}
$$

taken into account in $\left(1^{\prime}\right)$. The gross errors in the theory from such a substitution of the shortterm nonlinearity of concrete we considered in [4] and [8].

Famous foreign scientists renamed "fastflowing creep" into "minute creep", and the erroneous idea of the Second substitution is presented as their important achievement.

The principle of superposition in the theory of creep of concrete is a mathematical error committed in the exptensive interpretation of the principle of the linear superposition of Boltzmann. In international norms of reinforced concrete, it is estimated incorrectly: it is supposedly "a tendency to study creep ... according to the principle of superposition peculiar to Volterra's theory". Let us consider this in more detail.

We investigate the essence and the secondary nature of the Boltzmann scheme for the theory of creep of concrete on the example of concrete considered in the well-known paper of Maslov G.N. No. 4. Here the concrete has stationary properties corresponding to the classical theory. In the notation of Maslov G.N. the compliance function has the form

$$
J\left(t-t^{\prime}\right)=\Phi(t-\tau)=a-b e^{-\beta(t-\tau)},
$$

where

$$
a=\frac{C_{0}+E_{0}}{C_{0} E_{0}}
$$

$E_{0}$ is an elastic modulus;

$$
b=\frac{1}{E_{0}} ; \eta=\frac{C_{0}}{\beta},
$$

$\eta$ is a stationary coefficient of linear viscosity. In the theory of creep, the fundamental solution of the corresponding differential equation is known to have the form

$$
\varepsilon_{\sigma}(t)=\frac{\sigma(t)}{E_{0}}-\int_{t_{0}}^{t} \sigma\left(t^{\prime}\right) \frac{1}{E_{0}} \frac{\partial \varphi\left(t-t^{\prime}\right)}{\partial t^{\prime}} d t^{\prime}
$$

where

$$
\varphi\left(t-t^{\prime}\right)=E_{0} \frac{1}{C_{0}}\left[1-e^{-\beta\left(t-t^{\prime}\right)}\right]
$$

is characteristic of creep.

The Boltzmann case is obtained from the solution of (15) by means of a number of its transformations mathematically valid only under the conditions of stationary properties

$$
\begin{aligned}
& \varepsilon_{\sigma}(t)=\sigma_{0}\left\lfloor\frac{1}{E_{0}}+\frac{1}{E_{0}} \varphi\left(t-t_{0}\right)\right\rfloor+ \\
& +\int_{t_{0}}^{t}\left[\frac{1}{E_{0}}+\frac{1}{E_{0}} \varphi\left(t-t^{\prime}\right)\right] d \sigma\left(t^{\prime}\right)
\end{aligned}
$$

Unlike (15), the compliance function is used in the transformation $\left(15^{\prime}\right)$, which attracted the attention of scientists. However, the transformation $\left(15^{\prime}\right)$ is possible only with substantial and very strong restrictions. In the exptensive interpretation of compliance, these restrictions were not taken into account, and the theory of creep of concrete proved to be deeply erroneous.

Here, firstly, the property of the process that creates the temptation to expand the theory and transforms into the above-mentioned gross error 
for nonstationary $E\left(t^{\prime}\right)$ accompanying the normative linear creep theory of concrete is imposed on instantaneous deformation with an extremely simple physical meaning for an arbitrary t. In scientific literature there is even an authoritative statement that "elasticinstantaneous deformations strictly obey ... the principle of superposition".

Secondly, it is necessary to integrate (15) by parts, that in the exptensive interpretation of the compliance function under the conditions of ageing of concrete (1) creates another temptation, traditionally leading to another gross error in finding the core of the integral equation. As it is known, for non-stationary properties of concrete, the creep strain is obtained from another solution of differential equation, a solution written in a more complex form

$$
\begin{gathered}
\varepsilon_{c c}(t)=e^{-F(t)}\left\lfloor\varepsilon_{c 0}+\int_{t_{0}}^{t} \sigma(t) \frac{1}{\eta(t)} e^{F(t)} d t\right\rfloor, \\
F(t)=\int_{t_{0}}^{t} \beta(t) d t
\end{gathered}
$$

where the parameters $\eta(t)$ and $\beta(t)$ in (15) are functions of time.

In the concrete of Maslov G.N. the rate of deformation degenerates due to the difference kernel. In the case of an extensive interpretation of the compliance factor, the application of the Boltzmann principle usually becomes incorrect. The nonstationary model of Maslov concrete with a coefficient of viscosity

$$
\eta(t)=C_{0}(t) / \beta
$$

and a time-dependent module $E_{0}(t)$ demonstrates this:

- it satisfies experiments with simple loading at low levels $\sigma \approx 0,1 R_{\text {пр }}$;

- it satisfies the requirements of classical mechanics;

- it does not satisfy the conditions of the Boltzmann principle.
The Boltzmann principle distorts the essence of the nonstationary Maslov model. It replaces one classical body of creep of concrete with a chain model of successively connected bodies with a set of erroneous properties.

In the theory of creep of concrete, there is a case when extensive interpretation of the compliance function is unacceptable even with a difference kernel. For example, the nucleus of creep in a number of known works is represented in the form (the second case)

$$
K\left(t-t^{\prime}\right)=\frac{A e^{-\beta\left(t-t^{\prime}\right)}}{\left(t-t^{\prime}\right)^{\alpha-1}} .
$$

Certain forces correspond to this kinematic equation of motion in connection with the solution of the inverse problem of mechanics. The analysis of the differential creep equation reveals that in this nucleus there is a resistance force with a coefficient of viscosity of the linear model equal to

$$
\eta\left(t, t^{\prime}\right)=\frac{1}{A}\left(t-t^{\prime}\right)^{\alpha-1}
$$

which is impossible by the same reasons as in the above-mentioned case of applying the hereditary properties of the elastic modulus $E\left(t, t^{\prime}\right)$.

The third case corresponds to the extensive interpretation of the compliance function in the "chain model". This case is present in theoretical rheology, and as a repetition - in the norms of reinforced concrete.

We preliminarily write the Boltzmann scheme for the Maxwell body in the form

$$
\begin{aligned}
& \varepsilon_{\sigma}(t)=\sigma_{0}\left\lfloor\frac{1}{E_{0}}+\frac{1}{\eta}\left(t-t_{0}\right)\right\rfloor+ \\
& +\int_{t_{0}}^{t}\left[\frac{1}{E_{0}}+\frac{1}{\eta}\left(t-t^{\prime}\right)\right] d \sigma\left(t^{\prime}\right)
\end{aligned}
$$

where $\eta$ is a stationary coefficient of viscosity. With a variable viscosity coefficient 


$$
\eta(t)=\frac{E_{0}}{\dot{\varphi}(t)}
$$

we obtain the theory of ageing of concrete (Dischinger, Whitney);

$$
\varphi(t)=\varphi_{\infty}\left(1-e^{-b t}\right)
$$

which by series expansion gives the function of Freudenthal

$$
\varphi(t)=\frac{\varphi_{\infty} t}{\frac{1}{b}+t},
$$

substantiated by the experiments of Davis and Glanville.

In the "chain model", by successively connecting bodies (15) and (16), we have an extension record of the compliance function

$$
\begin{aligned}
J\left(t-t^{\prime}\right)= & \frac{1}{E_{0}}+\frac{1}{E_{0}} \varphi\left(t-t^{\prime}\right)+ \\
& +\frac{1}{\eta}\left(t-t^{\prime}\right)
\end{aligned}
$$

A pair of integral equations corresponding to the expansion hypothesis (17), and solved either with respect to deformations $\varepsilon_{\sigma}(t)$, or relative to the stresses $\sigma(\mathrm{t})$, in theoretical rheology are called "Boltzmann-Volterra equations"; It is also indicated that this pair "represents a complete mathematical formulation of the principle of linear superposition."

However, such a chain model, with its extensive interpretation of the compliance coefficient, is essentially erroneous; This is evidenced by its reduction to a differential form:

$$
\begin{aligned}
& \ddot{\varepsilon}_{\sigma}(t) \frac{\eta}{\beta}+\dot{\varepsilon}_{\sigma}(t) \eta=\ddot{\sigma}(t) \frac{\eta}{E_{0} \beta}+ \\
& +\dot{\sigma}(t)\left(\frac{\eta}{E_{0}}+\frac{1}{\beta}+\frac{\eta}{C_{0}}\right)+\sigma(t)
\end{aligned}
$$

It can be seen from (17 ') that there is a resistance force

$$
\ddot{\varepsilon}_{\sigma}(t) \frac{\eta}{\beta}
$$

proportional to the acceleration, which is incompatible with classical mechanics, and, in connection with Art. 5.1.1 (3) P Eurocode 0, the chain model is an inappropriate design model.

The components of the force of the computational model can be a function of position $\varepsilon_{\sigma}(t)$, speed $\dot{\varepsilon}_{\sigma}(t)$, time and other quantities. If there is (among others) a force proportional to acceleration $\ddot{\varepsilon}_{\sigma}(t)$, then the fundamental principle of mechanics about the independence of the action of forces is violated. The well-known scientist Pare L. has established the unacceptability of such forces in both problems of mechanics and in applications [6].

Unfortunately, in the scientific literature on concrete, in international norms, there are a number of errors analogous to those described, and consisting in an extensive interpretation of the compliance function in the form of a chain model [1], including for taking into account the rapidly flowing creep.

Thus, in the case of consistent merging of Maslov's theory and the theory of ageing of concrete (McHenry, Yashin A.V., Hansen T., Prokopovich I.E. and Ulitsky I.I.), the creep equation has the form

$$
\begin{aligned}
& \ddot{\varepsilon}(t)+\beta \dot{\varepsilon}(t)=\ddot{\sigma}(t) \frac{1}{E_{0}}+ \\
& +\dot{\sigma}(t)\left(\frac{\dot{\varphi}_{t}}{E_{0}}+\frac{\beta}{E_{0}}+\frac{\beta}{C_{0}}\right)+ \\
& +\sigma(t)\left(\frac{\ddot{\varphi}_{t}}{E_{0}}+\frac{\dot{\varphi}_{t}}{E_{0}}\right)
\end{aligned}
$$

If another viscous element with viscosity

$$
\eta(t)=\Delta e^{-\alpha_{1} t}
$$


is added to this chain in order to take into account the rapidly flowing creep, that was previously assumed by the Eurocode developers before its approval, then we get another erroneous version of the theory (written without averaging)

$$
\begin{aligned}
& \ddot{\varepsilon}(t)+\beta \dot{\varepsilon}(t)=\ddot{\sigma}(t) \frac{1}{E_{0}}+ \\
& +\dot{\sigma}(t)\left(\frac{\dot{\varphi}_{t}}{E_{0}}+\frac{\beta}{E_{0}}+\frac{1}{\eta(t)}\right)+ \\
& +\sigma(t)\left(\frac{\ddot{\varphi}_{t}}{E_{0}}+\frac{\beta \dot{\varphi}_{t}}{E_{0}}+\frac{\beta}{\eta(t)}-\frac{\dot{\eta}(t)}{\eta^{2}(t)}\right) .
\end{aligned}
$$

When Eurocode 2 was adopted, the theory of ageing and the viscous element were removed from this model, the error was annulled. In the Eurocode rules, only classic concrete Maslov G.N. is left; from its creep characteristics, a normative coefficient of creep development is obtained

where

$$
\beta_{c}\left(t, t_{0}\right)=\left[\frac{t-t_{0}}{\beta_{\mathrm{H}}+t-t_{0}}\right]^{0,3},
$$

$$
\beta_{\mathrm{H}}=1 / \beta \text {. }
$$

It is obtained by decomposing

$$
e^{-\beta\left(t-t_{0}\right)}
$$

in a series using two terms. The exponent 0.3 of the power function takes into account on average the ageing of the concrete.

In the case of nonlinear creep and short-term non-linearity in Eurocodes, the use of the Boltzmann scheme is also erroneous. For nonlinear creep of concrete of Maslov G.N. (the fourth case) within the framework of generally accepted hypotheses, the rate of deformation is

$$
\begin{aligned}
& \mathrm{v}_{\sigma}\left\{t, t^{\prime}, F\left[\mu\left(t^{\prime}\right), t^{\prime}\right]\right\}= \\
& \dot{\sigma}\left(t^{\prime}\right) \cdot F\left[\mu\left(t^{\prime}\right), t^{\prime}\right] \frac{1}{E_{0}} \varphi\left(t-t^{\prime}\right)+ \\
& +\sigma\left(t^{\prime}\right) \cdot \dot{\mu}\left(t^{\prime}\right) \frac{\partial F\left[\mu\left(t^{\prime}\right), t^{\prime}\right]}{\partial \mu} \frac{1}{E_{0}} \varphi\left(t-t^{\prime}\right)+ \\
& +\sigma\left(t^{\prime}\right) \cdot \frac{\partial F\left[\mu\left(t^{\prime}\right), t^{\prime}\right]}{\partial t^{\prime}} \frac{1}{E_{0}} \varphi\left(t-t^{\prime}\right)+ \\
& +\sigma\left(t^{\prime}\right) \cdot F\left[\mu\left(t^{\prime}\right), t^{\prime}\right] \odot \\
& \odot \frac{1}{E_{0}}\left[\frac{\partial \varphi\left(t-t^{\prime}\right)}{\partial t}+\frac{\partial \varphi\left(t-t^{\prime}\right)}{\partial t^{\prime}}\right],
\end{aligned}
$$

which is not taken into account in the traditional theory. Here $F\left[\mu\left(t^{\prime}\right), t^{\prime}\right]$ is a non-linearity function, in which the voltage

$$
\mu\left(t^{\prime}\right)=\sigma\left(t^{\prime}\right)
$$

is usually taken (after the work of Leaderman) as a nonlinearity parameter, which is incorrect: the methods of classical mechanics show that such an assumption is a very superficial assumption. We will devote a separate article to this problem.

For example, under this assumption, a series of multiple Volterra-Frechet integrals

$$
\begin{aligned}
& \varepsilon_{\sigma}(t)=\int_{-\infty}^{t} J_{1}\left(t-t^{\prime}\right) d \sigma\left(t^{\prime}\right)+ \\
& +\int_{-\infty}^{t} \int_{-\infty}^{t} J_{2}\left(t-t^{\prime}, t-t^{\prime \prime}\right) d \sigma\left(t^{\prime}\right) d \sigma\left(t^{\prime \prime}\right)+\ldots
\end{aligned}
$$

is a nonintegral form [10]

$$
\begin{aligned}
& \varepsilon_{\sigma}(t)=J_{1}(t) \sigma+J_{2}(t, t) \sigma^{2}+ \\
& +J_{3}(t, t, t) \sigma^{3}+\ldots
\end{aligned}
$$

Recently, some papers have appeared that develop "a modification of the principle of superposition of deformations for nonlinear creep" in the form 


$$
\begin{aligned}
& \varepsilon\left(t, t_{0}\right)=\varepsilon\left(t_{0}\right)+ \\
& +\int_{t_{0}}^{t}\left[\frac{1}{E(\tau)}+C(t, \tau)\right] d \sigma_{\mathrm{c}}(\tau)
\end{aligned}
$$

where

$$
\sigma_{\mathrm{c}}(\tau)=S[\sigma(\tau)]
$$

is the known stress function $\sigma[\tau]$.

The error of this formulation is similar to that used in (1). The total strain rate here is

$$
\begin{aligned}
& \left.v_{\sigma}(t, \tau)=\dot{S}[\sigma(\tau)] \mid \frac{1}{E(\tau)}+C(t, \tau)\right\rfloor+ \\
& +S[\sigma(\tau)] \frac{d}{d \tau} \frac{1}{E(\tau)}+ \\
& +S[\sigma(\tau)] \frac{\partial}{\partial \tau} C(t, \tau)+ \\
& +S[\sigma(\tau)] \frac{\partial}{\partial t} C(t, \tau) .
\end{aligned}
$$

From this it is clear that the last three terms in (18') are lost in (18). The significance of these terms is identical to the significance that we described in paragraphs 1-3 above. We must additionally pay attention to the fact that the identity of the nonlinear function $S[\sigma(\tau)]$ for short-term and long-term deformations is also incorrect. But even if another function $S_{g}[\sigma(\tau)]$ is used for creep strains, then, as it is noted above, this assumption is a very superficial assumption that does not correspond to the real nonlinear creep theory of concrete, which will be published later. This theory has nothing to do with the principle of superposition.

\section{REFERENCES}

1. Chiorino M.A. Analysis of Structural Effects of Time-Dependent Behavior of Concrete: An Internationally Harmonized Format // Concrete and Reinforced concrete - Glance at Future. 3rd All-Russian (International) Conference on Concrete and
Reinforced Concrete, Moscow, 2014. Vol. 7, Plenary Papers, pp. 338-350.

2. Fib, Model Code for Concrete Structures 2010, Ernst \& Sohn, 2013, 402 pages.

3. ACI 209.3R-XX, Analysis of Creep and Shrinkage Effects on Concrete Structures, Final Draft, Chiorino M.A. (Chairm. of Edit. Team), ACI Committee 209, March 2011, 228 pages.

4. Sanjarovsky R., Manchenko M. Oshibki v Teorii Polzuchesti Zhelezobetona i Sovremennye Normy [Errors in the Theory of Creep of Reinforced Concrete and Modern Norms]. // Structural Mechanics of Engineering Constructions and Buildings, 2016, No. 3, pp. 25-32.

5. Sanjarovskiy R., Ter-Emmanuilyan T., Manchenko M. Creep of Concrete and Its Instant Nonlinear Deformation in the Calculation of Structures. // CONCREEP 10, 2015, pp. 238-247.

6. Pars L.A. Analiticheskaja Dinamika [A Treatise on Analytical Dynamics]. Moscow, Nauka, 1971, 636 pages.

7. Polzuchest' i Usadka Betona i Zhelezobetonnyh Konstrukcij. Sostoyanie Problemy i Perspektivy Razvitiya [Creep and Shrinkage of Concrete and Reinforced Concrete Structures. State of the Problem and Development Prospects. GOSSTROJ USSR; NIIZB. Moscow, Strojizdat, 1976, 351 pages.

8. Sanzharovskij R.S, Manchenko M.M. Oshibki Mezhdunarodnyh Norm po Zhelezobetonu i Pravila Evrokoda [Errors of International Standards on Reinforced Concrete and Rules of the Eurocode]. // Structural Mechanics of Engineering Constructions and Buildings, 2017, No. 6, pp. 25-36.

9. Veryuzhskij Yu.V., Golyshev A.B., Kolchunov Vl.I., Klyueva N.V., Lisicin B.M., Mashkov I.L., Yakovenko I.A. Spravochnoe Posobie po Stroitel'noj Mekhanike [Reference Manual for Structural Mechanics]. V 2 Tomah. 
Tom 1. Moscow, Izdatel'stvo ASV, 2014, pp. 506-508.

10. Rabotnov Yu.N. Elementy Nasledstvennoj Mekhaniki Tverdyh Tel [Elements of Hereditary Mechanics of Solids]. Moscow, Nauka, 1977, 383 pages.

\section{СПИСОК ЛИТЕРАТУРЫ}

1. Chiorino M.A. Analysis of Structural Effects of Time-Dependent Behavior of Concrete: An Internationally Harmonized Format // Concrete and Reinforced concrete - Glance at Future. 3rd All-Russian (International) Conference on Concrete and Reinforced Concrete, Moscow, 2014. Vol. 7, Plenary Papers, pp. 338-350.

2. Fib, Model Code for Concrete Structures 2010, Ernst \& Sohn, 2013, 402 pages.

3. ACI 209.3R-XX, Analysis of Creep and Shrinkage Effects on Concrete Structures, Final Draft, Chiorino M.A. (Chairm. of Edit. Team), ACI Committee 209, March 2011, 228 pages.

4. Санжаровский Р.С., Манченко М.М. Ошибки в теории ползучести железобетона и современные нормы. // Строительная механика инженерных конструкций и сооружений, 2016, №3, c. 25-32.

5. Sanjarovskiy R., Ter-Emmanuilyan T., Manchenko M. Creep of Concrete and Its Instant Nonlinear Deformation in the Calculation of Structures. // CONCREEP 10, 2015, pp. 238-247.

6. Парс Л.А. Аналитическая динамика. М.: Наука, 1971. - 636 с.

7. Ползучесть и усадка бетона и железобетонных конструкций. Состояние проблемы и перспективы развития / ГОССТРОЙ СССР; НИИЖБ. - М.: Стройиздат, 1976. - 351 с.

8. Санжаровский Р.С., Манченко М.М. Ошибки международных норм по железобетону и правила Еврокода // Строительная механика инженерных конструкций и сооружений, 2017, №6, c. 25-36.

9. Верюжский Ю.В.,

Голышев А.Б., Колчунов Вл.И., Лисицин Б.М., Клюева Н.В., Машков И.Л., Яковенко И.А. Справочное пособие по строительной механике. В двух томах. Том 1. - М.: Издательство АСВ, 2014, c. 506-508.

10. Работнов

Ю.H.

Элементы наследственной механики твердых тел. М.: Наука, 1977. - 383 с.

Rudolf S. Sanzharovsky, Professor, Dr.Sc., Principal Researcher, L.N. Gumilyov Eurasian National University; 2 Mirzoyan str., Astana, 010008, Republic of Kazakhstan; phone +7 (7172) 709500, e-mail: enu@enu.kz.

Tatyana N. Ter-Emmanuilyan, Grand Ph.D., Professor, Professor of Department of Theoretical Mechanics, Russian University of Transport (RUT - MIIT); 9b9 Obrazcova St., Moscow, 127994, Russian Federation; phones: +7(499) 978-16-73; 20-13; 24-56;

E-mail: ipss@miit.ru.

Maxim M. Manchenko, Ph.D., Senior Researcher, Krylov State Research Centre; 44 Moskovskoe shosse, St. Petersburg, 196158, Russian Federation;

E-mail: salsa87@bk.ru.

Санжаровский Рудольф Сергеевич, профессор, доктор технических наук, главный научный сотрудник, Евразийский национальный университет им. Л.Н. Гумилева; 010008, Республика Казахстан, г. Астана, ул. Сатпаева, д. 2; тел. +7 (7172) 709500;

E-mail: enu@enu.kz.

Тер-Эммануильян Татьяна Николаевна, профессор, доктор технических наук; профессор кафедры «Теоретическая механика», Российский университет транспорта (МИИТ); 127994, Россия, г. Москва, ул. Образцова, 9б9; тел. +7(499) 978-16-73; 20-13; 24-56;

E-mail: ipss@miit.ru.

Манченко Максим Михайлович, кандидат технических наук, старший научный сотрудник, ФГУП «Крыловский научный центр»; 196158, Россия, г. Санкт-Петербург, Московское шоссе, д. 44;

E-mail: salsa87@bk.ru. 